ELORE (ISSN 1456-3010), vol. $12-2 / 2005$.

Julkaisija: Suomen Kansantietouden Tutkijain Seura ry. Taitto: Jukka Talve ja Outi Fingerroos.

[http://cc.joensuu.fi/ /oristi/2_05/kos2_05.pdf]

\title{
Ajankohtaista:
}

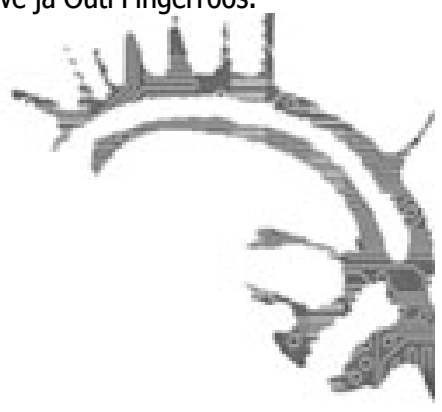

\section{TARINAMATKALLA ISLANNISSA}

5th Celtic-Nordic-Baltic Folklore Symposium on Folk Legends, Reykjavík 14.-18.6.2005.

Kaarina Koski

Tarinatutkimus on ollut Suomessa jo vuosikymmeniä niin epämuodikasta, että jos aiheesta haluaa käydä tieteellistä keskustelua, on parasta lähteä ulkomaille juttukavereita etsimään. Kelttiläis-pohjoismais-balttilainen tarinasymposiumi Islannissa viime kesäkuussa oli erinomainen foorumi tähän tarkoitukseen. Reykjavíkissa sijaitsevaan, Alvar Aallon suunnittelemaan Pohjolan taloon kokoontui neljän päivän ajaksi viitisenkymmentä folkloristia ja muuta tutkijaa, joista valtaosa oli paikalla keskustellakseen aivan vapaaehtoisesti nimenomaan tarinoista.

Kokouksen kelttiläis-pohjoismais-balttilaisuus vaikutti ensi näkemältä siltä, että osallistujat joko edustivat itse näitä mainittuja kansoja tai tutkivat niiden traditioita. Tällaisella rajauksella oli kuitenkin myös tieteellisiin intresseihin kiinnittyvä taustansa. Sarjan aikaisempien symposiumien ydinjoukko tutki nimenomaan näiden kansojen välisiä kontakteja, erityisesti Britannian kelttien suhteita muinaisskandinaaveihin. Suomalaiselle osallistujalle ensimmäisiä hämmästyksen aiheita olikin se, että arvostetut tutkijat analysoivat yksittäisten tarinatyyppien yhteyksiä toisiinsa Pohjanmeren eri rannoilla. Sellainen intressi haiskahti liian maantieteellis-historialliselta ollakseen totta vuonna 2005. Kuitenkin se on yllättävän ajankohtainen, kun otetaan huomioon viime aikoina kasvanut yleinen kiinnostus kelttejä ja skandinaavista mytologiaa kohtaan, mikä näkyi selvästi myös Brittein saarilla kukoistavaa uuspakanismia käsittelevissä esitelmissä. Näillä tarinavertailuja ja yksittäisten tarinatyyppien tai motiivien analyyseja esittelevillä konkareilla (esimerkiksi Bo Almqvist, Bengt af Klintberg, John Lindow, Ulf Palmenfelt) oli sitä paitsi myös ehdottomasti ajankohtaista sanottavaa.

\section{TulKINTA SOSIAALISESSA JA HISTORIALLISESSA KONTEKSTISSA}

Tarinasymposiumin alaotsikkona oli "Yhteisö ja historia", ja yksi kokouksessa näkyvistä pääsuuntauksista oli vanhojen tarinoiden tulkitseminen ennen kaikkea yh- 


\section{KaARINA KOSKI}

teisöllisten suhteiden kautta tai kansanomaisten asenteiden heijastajina erilaisissa historiallisissa ja poliittisissa tilanteissa. Tämän suuntauksen perinteistä laitaa edusti Bo Almqvistin analyysi Ihminen yliluonnollisen olennon kätilönä -tarinasta. Tarinatyyppien, motiivien ja niiden levinneisyyden tuntemus yhdistettiin siinä sosiaaliseen kontekstualisointiin. Esitelmä keskittyi kätilötarinan islantilaisversioiden ominaislaatuun muualla tavattuihin verrattuna ja suhteutti niitä paikallisiin oloihin. Almqvistin mukaan kyseessä on eräänlainen initiaatiotarina, joka symboloi siirtymää lapsesta aikuiseksi ja vastuunottamista itsestä ja itsensä elättämisestä: ammatin hankkimista. Tarinaa on kerrottu erityisesti taitaviksi tunnetuista kätilöistä, ja jotkut heistä ovat kertoneet myös itse saaneensa taitonsa ollessaan maahisten kätilönä. Pohdittiin, miksi islantilaisversioissa suhde maahisiin on selvästi ystävällismielisempi kuin muualla. Almqvistin tarjoama selitys islantilaistarinoiden yleiseen myönteisyyteen supranormaaleja olentoja kohtaan on saaren asukkaiden vähyys. Selitys perustuu näkemykseen tuonpuoleisista olennoista vieraiden ihmisten kuvana. Koska väkeä on vähän, todennäköisyys joutua uudelleen tekemisiin samojen ihmisten kanssa on suuri. Tämä tekee tuntemattomien ihmisten petkuttamisesta vähemmän houkuttelevaa, koska riski törmätä huijaamiinsa ihmisiin ja joutua vastuuseen on todellinen: jonkinlainen sosiaalinen kontrolli ulottui pienissä piireissä siis myös tuntemattomiin ihmisiin. Tällöin vierailtakaan ihmisiltä ei ole yhtä yleisesti kuin muualla tarvinnut odottaa petosta tai arvaamatonta käytöstä.

Historialliseen ja sosiaaliseen ympäristöön kontekstualisoiva suuntaus näkyi symposiumissa toisaalta näkökulmana tarinoiden normatiiviseen aspektiin meidän ja muiden tai sopivan ja sopimattoman välisen rajan ilmaisijoina. Toisaalta tarkasteltiin tarinoita poliittisten tai yhteiskunnallisten muutosten rajakohdissa: Eda Kalmre tutki vuosille 1946-1947 sijoittuvaa tarinaa Tartossa sijainneesta "makkaratehtaasta", jolla viitattiin valloittajien harjoittamaan kannibalismiin. Guntis Pakalns käsitteli kansallisen identiteetin ja uuden poliittisen suunnan muovaamista latvialaisissa nykytarinoissa vuoden 1991 vallankumouksen jälkeisenä aikana. Timothy Tangherlini taas tulkitsi vanhempaa tanskalaista tarina-aineistoa 1800-luvulla tehtyä lakiuudistusta ja sen vaikutuksia vasten. Tangherlinin esitys osoitti selvästi yhteiskunnallispoliittisen lähestymistavan toimivuuden myös vanhoissa aineistoissa.

Kaikki symposiumin osallistujat eivät olleet taustaltaan folkloristeja. Islannissa folklorea on saagojen myötä tutkittu perinteisesti myös kirjallisuudentutkimuksen puolella. Valopilkku sosiaalihistorian piiristä oli David Hopkin, jonka suurena missiona brittiläisten kollegojensa parissa on tuoda folkloreaineistot ja niiden tulkinnan välineet historiantutkimukseen. Hänen menetelmänään on toisaalta houkutella eritoten ulkomaisia folkloristeja historian alan kokouksiin tekemään vaikutus, toisaalta tehdä itse vakuuttavaa tutkimusta folkloreaineistojen parissa. Hopkinin esitelmän aiheena Islannissa oli vanhan Gargantua-tarinan käyttö argumenttina ranskalaisten kylien välisessä kalastusaluekiistassa. Muissa tutkimuksissaan (Hopkin 2000) hän on käyttänyt aineistonaan vakuuttavasti myös satuja ja kansanomaisia uskomuksia. Tällaiset folkloristiset täsmäanalyysit ovatkin hämmästyttävän tehokkaita historiantutkimuksen aukkopaikoissa.

Hopkinin ja Tangherlinin kaltaiset esitykset näyttivät konkreettisesti histo- 
torian ja folkloren yhdistämisen hedelmällisyyden, vaikkei yhdistelmä ole suomalaisenkaan folkloristiikan piirissä uusi.

\section{MIKÄ ON TARINA?}

Tarinoita koskevien teoreettisten puheenvuorojen sektori oli symposiumissa kapea mutta terävä. Plenaaritasolla Anna-Leena Siikala sai vastata yksin perinnelajikäsitteen teoreettisesta ravistelusta. Vaikka näkökulman laajennus perinnelajeista typologisena järjestelmänä genreihin tulkinnan kehyksinä ja tuottamisen strategioina on kehkeytynyt folkloristiikankin piirissä jo vuosia, se tuntuu välillä jääneen syrjään tarinan genreä määrittelevässä debatissa. Juuri tästä kysymyksestä olisi ollut kiinnostavaa kuulla enemmän myös kuulijoiden kommentteja. Miten tyyppiluetteloidensa äärellä ahkeroivat tutkijat ottivat tämän vastaan? Siikala kytki diskurssin elementtinä käsittelemänsä genren sosiaalisen todellisuuden tuottamiseen ja prosessointiin. Erilaisina esimerkkeinä sosiaalisen todellisuuden tuottamisesta kerronnan avulla olivat Cookinsaaret, komilaiskylä ja Pohjanmaan Kauhajoki. Näiden kautta näkyi selvästi kulttuurien tasolla kerronnan merkitysten ja tavoitteidenkin erilaisuus. Kerrontadiskurssit on eri kulttuureissa institutionalisoitu eri tavoin, ja siksi niiden kulttuurinen paikka ja merkitys vaihtelee. Kysymykseen tarinan genren yleismaailmallisuudesta Siikala otti sovittelevan kannan. Vaikka joka kulttuurissa on erilaiset järjestelmänsä eivätkä eurooppalaiset käsitteet sovi joka paikkaan, totutut lajisysteemimme ovat tarpeellisia ja auttavat myös näkemään erot muuhun maailmaan nähden.

Keskustelu tarinasta perinnelajina ei valitettavasti jatkunut yleisellä foorumilla. Käytävät ja kahvipöydät ovatkin käytännössä mielipiteiden vaihdolle otollisempia paikkoja. Ja juuri niissä olosuhteissa kävi jo ennen symposiumin avausta ilmi se myöhemmin vahvistunut tuntu, että skandinaavis-kelttiläisen vertailevan tarinatutkimuksen piirissä tarinoilla tarkoitetaan ensisijaisesti fabulaatteja tai vaellustarinoita: juonellisesti kiinteitä ja motiivistoltaan laajalti tunnettuja kertomuksia. Toisin sanoen saatoin havaita hienoista paheksuntaa sitä kohtaan, että tarinan käsitettä laajennetaan saman tarinatyypin sisältöä edustavien memoraattien ja uskomusten suuntaan. Taustalla on näkemysero siitä, ovatko tarinatutkimuksen kohteena perinteiset, katalogisoitavissa olevat fabulaatit, vai käsitelläänkö tarinoina myös keskustelunomaisia kommentteja ja uskomuslauseita, jotka sisältävät saman idean, "tarinaytimen", kuten Linda Dégh asian ilmaisee. Hänen edustamassaan tarinan etnografiassa saman idean representaatioiden koko skaalan katsotaan antavan merkityksistä täydemmän kuvan kuin pelkät fabulaatit. Déghin mukaan tarinansisäinen lajittelu ylipäätään perustuu vain pinnallisiin muuttujiin. (Dégh 2001, 97, 99, 102.) Lajittelun puolesta kuitenkin puhuu se, että erilaisissa muodoissaan esitettynä sama idea voi saada hyvinkin erilaisen tulkinnan ja tehtävän. Näiden näkemysten ei tarvitsisi olla keskenään vastakkaisia vaan toisiaan täydentäviä. Jälleen kerran kiista terminologiasta ja määritelmistä perustuu siihen, mistä näkökulmasta asioita halutaan lähestyä. Ehkä oli viisastakin, ettei kumpaakaan näkökulmaa ruvettu eksplisiit- 
tisesti julistamaan plenaariluennoilla. Vaikka terminologian väljyys koetaan usein haitaksi, olisi vielä haitallisempaa sulkea asiaa eri näkökulmasta tarkastelevat tutkijat sen piiristä pois.

\section{ESTETIIKKA JA SYMBOLINEN TULKINTA}

Tarinan mieltäminen ensisijaisesti fabulaatiksi merkitsee genren rajaamista eräänlaisella esteettisellä muotoperusteella ja tarinoiden lähestymistä kansanomaisena, suullisena proosana, jossa sanottavalla usein on symbolinen muoto. Jos kyseessä ovat uskomustarinat - kuten Islannissakin suureksi osaksi - tällöin ei etsitä kertomuksen yhteyttä supranormaalia koskevaan uskoon ja elämyksiin, vaan tarkastellaan sen sanomaa metaforisena puheenvuorona. Tällainen näkökulma kertomusperinteeseen on Suomessa ollut pitkään marginaalinen. Meillä on tehty merkittäviä tarinoiden kerrontaa valottavia tutkimuksia, joissa pääpaino on ollut kerronnan tuottamisessa ja merkitysten muotoutumisessa (tunnetuimpia Siikala 1984 ja KaivolaBregenhøj 1988). Uskomussisällön osalta taas tarinat jäivät 1960-luvulta lähtien memoraattien varjoon. Painava merkityksensä tässä kehityksessä oli Lauri Hongon ja Juha Pentikäisen 1960-1970-luvuilla muotoilemalla, uskontotieteellisellä tutkimusintressillä, joka omaksuttiin folkloristiikkaan heidän tekemiensä tutkimusten lisäksi oppikirjojen kautta (ks. esim. Honko \& Pentikäinen 1970, 57-58). Jäljitettäessä aitoja uskonnollisia elämyksiä tarinat eivät soveltuneet lähdeaineistoksi, ja genreanalyyttista näkökulmaa käytettiin mahdollisimman aitojen memoraattien seulomiseksi esiin. Islannista saakka katsottuna tämän näkökulman voimakas dominanssi Suomessa näytti pieneltä, paikalliselta erikoisuudelta. Ehkäpä voisimmekin jo toipua 1970-luvusta ja alkaa tutkia "aidon kansanuskon" lisäksi myös tarinoita, jotka käsittelevät omalla epäsuoralla tavallaan arkeen, sosiaaliseen ympäristöön ja moraaliin liittyviä kysymyksiä? Suomen ruotsinkieliset folkloristit ovat seuranneet tässä suhteessa pikemminkin skandinaavista linjaa ja tutkineet laajemmin myös elämyksiin liittymätöntä kerrontaa ja sen merkityksiä (esim. Wolf-Knuts 1991; Asplund 2004).

Outi Lehtipuron mukaan kiinnostuksen kohdistuminen tekstien takana oleviin ajattelutapoihin ja maailmankuviin on ollut yleinen ilmiö suomalaisessa folkloristiikassa samalla kun esteettinen aspekti on jäänyt vähälle huomiolle sekä folkloren määrittelyssä että tutkimuksessa. Niin sanottu uusi folkloristiikka 1970luvun alussa määritteli folkloren taiteelliseksi kommunikaatioksi pienryhmissä. Suuntauksen myötä Suomessa omaksuttiin tutkimukseen performanssi- ja pienryhmäkeskeisyys, mutta sanoman pukeminen esteettiseen muotoon folkloren ominaisuutena ei löytänyt silloin kannattajia meillä. (Lehtipuro 2002, 66-68.)

Tarinan käsite on hyvin laaja, ja Islannissakin käsiteltyjen aineistojen skaala ulottui fabulaateista huhuihin ja uskomuksiin. Islannin tuliaisina luotan siihen, että tarinoita kannattaa tutkia ja että fabulaatit - tyyppitarinat ja vaellustarinat ansaitsisivat myös Suomessa enemmän tutkimuksellista huomiota. Täydellisimmillään fabulaatit ovat kansanomaista proosaa, kokonaisia kertomuksia, joita voi käyttää 
vertauskuvina, malleina, varottavina esimerkkeinä tai argumentteina. Viihdyttävä muoto auttaa sanoman perillemenoa. Vaikka sanoma voi jäädä viihteen varjoon, tulkitsija käsittänee, että myös viihdyttävyys kärsii, jos kertomuksen sisältämä sanoma ei ole kuulijoiden mielestä hyväksyttävä. Jo sillä perusteella, että yhteisön jäsenet ovat tunteneet yleisimmät tarinat ja että niiden sisältämät sanomat yleensä käsittelevät normeja ja moraalia, fabulaattien sivuuttamista kansanuskontutkimuksessakaan pelkkänä viihteenä ei enää voi pitää oikeana ratkaisuna.

\section{KirjallisuUs}

ASPLUND INGEMARK, CAMILLA 2004: The Genre of Trolls. The Case of a Finland-Swedish Folk Belief Tradition. Åbo: Åbo Akademis Förlag, Åbo Akademi University Press.

DÉGH, LINDA 2001: Legend and Belief. Dialectics of a Folklore Genre. Bloomington: Indiana University Press.

HONKO, LAURI \& PENTIKÄINEN, JUHA 1970: Kulttuuriantropologia. Porvoo: WSOY.

HOPKIN, DAVID M. 2000: La Ramée, the Archetypal Soldier, as an Indicator of Popular Attitudes to the Army in Nineteenth-Century France. - French History 14(2): 115-149.

KAIVOLA-BREGENHØJ, ANNIKKI 1988: Kertomus ja kerronta. Suomalaisen Kirjallisuuden Seuran Toimituksia 480. Helsinki: Suomalaisen Kirjallisuuden Seura.

LEHTIPURO, OUTI 2002: Kolmas esteettinen kulttuuri? - Sepänmaa, Yrjö \& Heikkilä-Palo, Liisa (toim.), Vesi vetääpuoleensa. Helsinki: Maahenki Oy.

SIIKALA, ANNA-LEENA 1984: Tarina ja tulkinta. Tutkimus kansankertojista. Suomalaisen Kirjallisuuden Seuran Toimituksia 404. Helsinki: Suomalaisen Kirjallisuuden Seura.

WOLF-KNUTS, ULRIKA 1991: Människan och djävulen. En studie kring form, motiv och funktion i folklig tradition. Åbo: Åbo Akademis Förlag - Åbo Akademi University Press.

Kirjoittaja on filosofian maisteri ja valmistelee väitöskirjaansa Helsingin yliopistossa. 